\title{
Effect of Family Assistance During Operation on The Level of Anxiety of Sectio Caesarea Patients in RSIA Stella Maris Medan
}

\section{Suherni}

STIKes Flora Medan

\begin{abstract}
Surgical action is one of the potential and actual threats to the integrity of a person who can arouse anxiety when dealing with it, so there is a need for psychological preparation when facing surgery. The most common surgical procedure is sectiocaesarea. In sectiosaesarea surgery a mother will experience anxiety, of course this can be dangerous if not handled properly. One of the treatments is with good psychological preparation that is from yourself and support from the closest family. The type of research used was observational analytic with the aim to determine the effect of family assistance during surgery on the anxiety level of Sectio Caesarea patients. The population in this study were all patients postoperative caesarean section. The sample used with the Purposive Sampling method is the technique of determining the sample based on certain considerations, the sample size is 50 respondents. The data processing tool used is SPSS 17.0 For Windows Release. The Mann-Whitney Test was used to analyze data. The results showed p-value = 0,000 ( $\mathrm{p}$-value $<0.05$ ) which means that there were significant differences between the anxiety levels of group patients accompanied by families with those who were not accompanied by family during sectiocaesareasurgery.It is recommended to health services, especially the Stella Maris Hospital in Medan, to continue to facilitate families to assist patients who undergo surgical procedures for caesarean section so that they can reduce the level of anxiety for patients who will undergo surgery. Researchers expect that nurses can provide emotional support and motivation to patients to improve patient self-acceptance.
\end{abstract}

Keyword: Family Assistance, Anxiety Level.

Received 04 February 2019 | Revised 14 May 2019 | Accepted 26 January 2019

\section{Introduction}

Pregnancy is a period of crisis that will end in labor. There are 2 types of labor, namely normal delivery through the vagina or labor by caesarean section or sectiocaesarea, namely through surgery where the incision is made in the mother's abdomen (laparatomy) and uterus (hysteretomy) to remove the baby (Cunningham, 2006).

*Corresponding author at: STIKes Flora Medan 
Childbirth with caesarean section is currently a growing trend. According to the World Health Organization (WHO) in 2014 the rate of childbirth through caesarean section continues to increase worldwide, especially in middle and high income countries, including Australia (32\%), Brazil (54\%) and Colombia ( 43\%).

Indonesia the incidence of sectio caesarean surgery has increased every year. The Demographic and Indonesian Population Survey (SKDI) states that the number of mothers experiencing Sectio Caesarea is above 50\% of the total number of deliveries (Ministry of Health, 2014). This labor is mostly carried out in private hospitals, which are as much as $25 \%-30 \%$ compared to Government Hospitals, which are on average 15\% - $20 \%$.

Stella Maris Mother and Child Hospital Medan is one of the private hospitals that has quite a lot of deliveries with Sectio Caesarea. The initial survey conducted at the Stella Maris Hospital in Medan found that every year there was an increase in the number of Sectio Caesarea operations. Hospital data in 2016 amounted to $65 \%$ of the total deliveries, of which 2410 were Sectio Caesarea operations. With an average of 200 Sectio Caesarea operations every month. With the average incidence of primisectio or the first time sectiocaesarea in mothers was $41 \%$ ( 82 cases) in 2016.

The high incidence of Sectio Caesarea can not be separated from the factors that influence it. The most common indications for patients finally undergoing caesarean section were previous history of caesarean section, buttocks, distortion, fetal distress, severe preeclampsia, fetal distress, narrow pelvis, and placenta previa (Rasjidi, 2009). In addition, from the research of Mulyawati et al (2011), it can be seen that the factors associated with caesarean section delivery were maternal age, parity, and the incidence of anemia.

Although the procedure of sectiocaesarea is often done, but until now most people assume that surgery is a frightening experience. Where a surgical procedure can provide an emotional reaction such as fear, anger, anxiety and anxiety for the patient before facing it. One of the most common responses in pre-operative patients is the psychological response (anxiety), mentally the patient who will face surgery must be prepared because there is always anxiety and fear of injection, wound pain, anesthesia, and even the possibility of disability or death.

Surgical action is one of the potential and actual threats to the integrity of a person who can arouse anxiety when dealing with it, so there is a need for psychological preparation when facing surgery. The results of the Montgomery et al (2011) study in New York, USA regarding preoperative psychological factors for postoperative side effects, showed that preoperative stress greatly contributed to the severity of postoperative pain and fatigue one week after surgery. Further anxiety can also increase the perception of pain, if anxiety does not get attention,then the anxiety will cause a serious problem in pain management.

This anxious reaction will continue if the client does not have someone who can support him during the operation process. In MOH RI (2011) states that since 2000 the government has 
launched Making Pregancy Safer (MPS) which is a health sector strategy focusing on systematic and integrated approaches and planning. One of them encourages the empowerment of women and families where the expected outcome of the strategy is to determine the involvement of the husband in promoting maternal health and increasing the active role of the family in pregnancy and childbirth.

Nolan (2004) mentions that one can reduce maternal pain during childbirth is mentoring from a husband or family, because the effects of feelings including anxiety for each mother are related to the perception of people who support presence. The presence of a childbirth companion influences the mother of childbirth because it can help the mother during labor both in normal labor and Sectio Caesarea and can provide attention, comfort, enthusiasm, reassure the mother, reduce maternal tension and emotional status.

Research conducted by Cholil (2006) mentions the effects of the absence of a husband's accompaniment during childbirth have an impact on maternal anxiety resulting in excessive kotekolamine levels which cause a decrease in collarymal blood flow, weak uterine contractions, decreased keplasenta blood flow, reduced oxygen available for the fetus can result in the length of labor.

Musbikin (2005) in his research stated that wives accompanied by families, especially husbands had fewer complications, the need for analgesics and medical therapy was also reduced, with the presence of delivery assistance also making the delivery time shorter and making the wife more calm, comfortable, far from postpartum depression and babies born in good health with good APGAR values.

Stella Maris Mother and Child Hospital Medan as one of the private hospitals with a fairly high number of deliveries in the city of Medan gives special attention in handling sectio caesarean deliveries, one of which is giving the family an opportunity to accompany patients during the sectiocaesarea procedure. But so far there has been no research regarding the role of family assistance during surgery on the condition of patients with cesarean section.

Based on the above, the researchers were interested in conducting research on the Effect of Family Assistance on the Anxiety Level of Sectio Caesarean Patients at Stella Maris Mother and Child Hospital Medan.

\section{Research Methods}

This study was an observational analytic study with a Cross Sectional approach. The sample in this study were all sectio caesarean patients in the operating room of Stella Maris Mother and Child Hospital Medan. Samples were taken by purposive sampling with inclusion criteria, namely willing to be respondents, patients who underwent elective caesarean section (planned), patients with only sectiocaesarea, PrimiSectio Caesarea patients. Data on the Effect of Family Assistance on the Anxiety Level of Patients with Sectio Caesarea at Stella Maris Mother and 
Child Hospital Medan obtained by using instruments questionnaire. This research was conducted by Stella Maris Mother and Child Hospital Medan.

The research was conducted for 1 year, starting in February 2018. The influence between independent variables (family assistance) and dependent variables (anxiety level of Sectio Caesarea patients) can be determined by comparing the results of Sectio Caesarea patient questionnaires with mentoring families and Sectio Caesarea patients without family assistance using the Mann Whitney statistical test.

\section{Research Result}

This research has been conducted since February 2018 at the Stella Maris Mother and Child Hospital in Medan. Effects of Family Assistance on Anxiety Levels Patients with sectiocaesarea were measured using standard instruments [20].

The results of the univariate analysis showed that the majority of respondents who were not accompanied by a family during the operation were at moderate to severe anxiety levels, namely the same as 9 people (36.0\%) and a small part which was on mild anxiety, namely 7 people (28.0\% ), and most of the respondents who were accompanied by the family during the operation were in mild anxiety as many as 19 people (76.0\%) and a small portion were in moderate anxiety ie 6 people $(24.0 \%)$.

The bivariate analysis results obtained from the Mann-Withney test obtained a significance number with $p$-value 0,000 . Because the value of $p<0.05$ can be concluded that there are significant differences between groups accompanied by families with groups not accompanied by families or in other words there are influences.

\section{Research Discussion}

\subsection{Univariate Analysis}

The results of this study indicate that most respondents did not accompanied by the family during the operation are at moderate to severe anxiety levels compared to respondents who were accompanied by the family during surgery are in mild anxiety

Table 1. Frequency Distribution and Percentage of Anxiety Levels of Sectio Caesarea Patients Not Accompanied by Families at Stella Maris Hospital in Medan.

\begin{tabular}{clcl}
\hline No & Anxiety Level Amount & N & Percentage \\
\hline 1 & Mild anxiety & 7 & $26,0 \%$ \\
\hline 2 & Moderate Anxiety & 9 & $36,0 \%$ \\
\hline 3 & Severe Anxiety & 9 & $36,0 \%$ \\
\hline
\end{tabular}




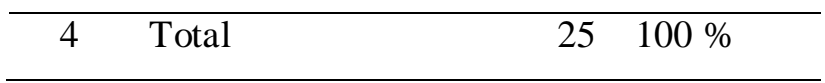

Based on the results of the study it was found that the majority of respondents who were not accompanied by the family during the operation were at moderate to severe anxiety levels which were as many as 9 people (36.0\%) for moderate anxiety levels of 9 people (36.0\%) for the level severe anxiety and and a small part which is on mild anxiety, namely 7 people $(28.0 \%)$.

Anxiety in the study was obtained because the perception of the community that considered delivery through surgery was still one thing that was quite frightening for patients. Same thing with the opinion of Aprinawati (2010) which states that anxiety is an unclear feeling of concern and worry because of the threat to the value system or someone's security pattern, individuals may be able to identify situations (eg labor) but in reality self-threats are related to worry and the concerns involved in these situations are the source of threats, but not the threat itself.

The results of this study are the same as the research conducted by Cut Ti Arra (2011) with a journal entitled maternal anxiety in the face of the process. labor where the result is that most mothers are in severe anxiety (53.3\%) moderate anxiety (40\%) and mild anxiety (6.7\%).

Table 2. Frequency Distribution and Percentage of Anxiety Level of Sectio Caesarea Patients Accompanied by Families at Stella Maris Hospital in Medan.

\begin{tabular}{clll}
\hline No & $\begin{array}{l}\text { Anxiety Level } \\
\text { Amount }\end{array}$ & $\mathrm{N}$ & Percentage \\
\hline 1 & Mild anxiety & 19 & $76.0 \%$ \\
\hline 2 & Moderate Anxiety & 6 & $24.0 \%$ \\
\hline 3 & Total & 25 & $100.0 \%$ \\
\hline
\end{tabular}

Based on the results of the study, it was found that the majority of respondents who were accompanied by the family during the operation were at the level of mild anxiety, namely as many as 19 people (76.0\%) and a small portion that was at moderate anxiety, namely 6 people (24.0\%). The results of this study are associated with the strong role of family support for the cesarean section delivery process. In accordance with the theory which states that the family is the substance closest to someone. The families who are closest and better understand the condition of family members in this case the mothers who give birth who really need emotional and physical support during the delivery process either normally or Sectio Caesarea. Rohma (2010) that continuous support from a companion to the mother during labor and cleansing process can facilitate the process of labor and delivery itself and reduce the need for other medical actions due to medical complications during labor.

2. Bivariate Analysis 
The results of the study found that there were significant influences or differences between groups accompanied by families with groups not accompanied by families. Based on the MannWithney test results obtained a significance number with

$\mathrm{p}$-value 0,000 ( $\mathrm{p}$ value $<0.05$ ). This shows that the assistance of the husband at the time of delivery has an effect on the smooth delivery of the mother, because indirectly the presence of a family has a positive impact on the psychological condition of the mother so that the delivery process can run smoothly. The things that were done by mentoring were giving support in the form of touch and prayer so that the mother felt calm when the operating procedure was carried out.

Table 3. Effect of Family Assistance on the Anxiety Level of Sectio Caesarea Patients at the RSIA Stella Maris Medan.

\begin{tabular}{llll}
\hline & \multicolumn{3}{c}{ Mann-Withney Test } \\
\hline & $\mathrm{Z}$ & $\mathrm{P}$ & Categories \\
\hline $\begin{array}{l}\text { Accompanied by } \\
\text { family }\end{array}$ & 5,225 & 0.0000 & There is influence \\
\hline $\begin{array}{l}\text { Accompanied by } \\
\text { family }\end{array}$ & - & - & - \\
\hline
\end{tabular}

The results of this study are in line with the theory of Indrayani (2013) who said that the presence of a birth attendant continuously will bring a good impact on labor because it can provide a sense of security, comfort and enthusiasm and emotional support that can also encourage the mother, reduce feelings get sick and speed up the labor process. Childbirth assistance is not absolute as the main factor in the smooth delivery process, but if things are ignored it will have a psychological effect on the mother because during labor the mother is very in need of the support of the closest person, the family. As research conducted by Penny (2005) about assisting husbands on the smooth delivery, it was stated that childbirth assistance was not an internal factor, but indirectly was very influential towards the mother's psychic so that can provide peace to the mother's heart which ultimately reduces anxiety.

If during labor the mother does not have the support and enthusiasm of the companion, the time of delivery can be long and if it has exceeded the alert line it can also affect the safety of the baby. This is in accordance with the opinion expressed by Simkin et al. (2005) which states that if the delivery process is not accompanied, usually this mother will feel afraid, anxious, feel insecure and comfortable until finally she will feel hopeless because no one gives encouragement, so a feeling of tension arises. This will hinder the labor process which results in stress on the mother and baby can occur so that pesalinan becomes not smooth.

A person who is accompanied during childbirth shows a psychological person who is better prepared to face labor than those who are not accompanied during labor. In accordance with 
Simkin et al (2005) fear, loneliness, stress or excessive anger can lead to the formation of catecholamines (stress hormones) and lead to progress in labor not smoothly.

The effect of family assistance on maternal anxiety levels in this study shows how important the role of the closest person in facing a critical period in his life. As revealed by Nolan (2010) that the presence of a husband or partner as a childbirth companion is strongly recommended to accompany the mother during labor, because a direct approach can encourage communication between partners so that they can overcome concerns and anxieties that arise in the mother during labor. psychological and hypoxia which can increase adrenaline secretion. With the presence of a husband besides the mother during the labor process, the mother will feel more calm and comfortable, the mother will feel that the husband is bearing her burden, the mother can divert the anxiety that comes with communicating with the husband, the mother feels enthusiasm and confidence from her husband's presence during labor.

The same thing was expressed by Musbikin (2005) who stated that wives accompanied by families, especially husbands had fewer complications, the need for analgesics and medical therapy was also reduced, with the presence of labor assistants also making the delivery time shorter and making the wife feel calm, comfortable, far from postpartum depression and babies born in good health with good APGAR values.

\section{Conclusion}

From the results of the study it was found that there was an influence (difference) between family assistance during surgery on the anxiety level of sectio caesarean patients with those who were not accompanied by family during surgery with a p-value: 0.000 where $p$-value $<0.05$, this indicates that mentoring the family at the time of delivery has an effect on the smooth delivery of the mother, because indirectly the presence of a family gives a positive impact on the psychological condition of the mother so that the delivery process can run smoothly.

\section{REFERENCES}

[1] Arikunto, Suharsimi. (2006). Prosedurpenelitiansuatupendekatanpraktik. Jakarta :RinekaCipta.

[2] Bobak, Irene. (2004). Buku Ajar KeperawatanMaternitas. Jakarta : EGC.

[3] Cunningham, Mac Donald, Gant. (2006). Obstetriwilliams, Jakarta : EGC.

[4] Dewi, KuraesisnSyarif. (2009). Skripsi :Fator-fator yang memengaruhitingkatKecemasanpasien yang akanmenjalanitindakanoperasi. Jakarta , UIN.

[5] Friedman, Marilyn M. (2010). Buku ajar keperawatankeluarga :Riset, Teori dan Praktek. Jakarta : EGC. 
[6] Hidayat, A.AzizAlimul. (2007). MetodePenelitianKeperawatan\&TeknikAnalisa Data, Jakarta, SalembaMedika.

[7] Kaplan \&Sadock. (2005). buku ajar psikiatriklinis. Ed Ke- 2. Jakarta : EGC.

[8] Long, Barbara, C. (1996). Perawatan medical Bedah Volume 2. Bandung:Yayasanikatan alumni pendidikankeperawatanpadjajaran.

[9] Maslim, R.. (2001). DiagnosisGangguanJiwa, RujukanRingkas PPDGJ - III, BagianIlmuKedokteranJiwa FK UnikaAtmajaya, Jakarta.

[10] Maulana, Heri, d.j, (2011). PromosiKesehatanJakarta : PenerbitBukuKedokteran EGC.

[11] Musbikin, Imam.(2005). Panduanbagiibuhamil\&melahirkan, Yogyakarta : MitraPustaka.

[12] Muttaqin,A., Sari, K,. (2009). AsuhanKeperawatanPerioperatif: Konsep, proses\&Aplikasi. Jakarta: SalembaMedika.

[13] Notoatmodjo, SoekidjoProf.Dr. (2007). IlmuPerilakuKesehatan. Jakarta. RinekaCipta.

[14] Nurhasanah, Nunung. (2010). Ilmu Komunikasi DalamKonteks Keperawatan untuk Mahasiswa Keperawatan. Trans Info Media.

[15] Polit, D. E \&Hungler, B. P. (1999). Nursing reaserch principles and methodes,Edisi 6., Philadelphia : Lippincott.

[16] Potter, P, A \& Perry, A, G. ( 2005).Buku AjarFudamentalKeperawatan Vol.2Edisi 4. Jakarta: EGC.

[17] Prabowo, Eko. (2014). Konsep\&AplikasiAsuhanKeperawatanJiwa. Yogyakarta Medical Book.

[18] Prawirohardjo, S. (2008). IlmuKebidanan. Jakarta :BinaPustaka

[19] Rasjidi, Imam. (2009). Manual SeksioSesarea\&LaparotomiKelainanAdneksa. Jakarta : CV SagungSeto.

[20] Setiadi.(2007).Konsep\&PenulisanRisetKeperawatan, Yogyakarta, Graha Ilmu.

[21] Stuart, G.W. (2007). BukuSakuKeperawatanJiwa. AlihBahasaAchi - yaniHamid. Jakarta: EGC.

[22] Suprajitno, (2004). Asuhan Keperawatan Keluarga :Aplikasi dalam praktik, Jakarta: EGC.

[23] Syafitri Endang \& sudaryanto Agus, (2010). Jurnal : Pengaruh Pemberian Informasi Prabedah Terahdap Tingkat Kecemasan Pasien pada Pasien Pra Bedah. Jakarta : RSUI.

[24] Wiknjosastro, Hanifa. (2009). IlmuKebidanan. Jakarta : YBP-SP 